\title{
THE EFFECTS OF HIGH DOSE MORPHINE AND MORPHINE PLUS NITROUS OXIDE ON URINARY OUTPUT IN MAN
}

\author{
Theodore H. Stanley, m.d. ${ }^{*}$, Neal H. Gray, m.D.,$\nmid$ Arun V. Bidwai, m.D. $\neq$ \\ and Robert LORDON, M.D. $\$$
}

LARGE DOSES of intravenous morphine $(0.5-4.0 \mathrm{mg} / \mathrm{kg})$ and oxygen has recently become popular as a method of anaesthetizing critically ill patients for cardiac and other major operative procedures. ${ }^{1,2}$ While the technique results in a minimum of cardiovascular depression, it has been suggested that a marked antidiuresis is associated with these doses of morphine. ${ }^{3}$ This study was conducted to determine the effects of morphine $(2 \mathrm{mg} / \mathrm{kg}$ ) and morphine plus 60 per cent nitrous oxide on the urinary output of patients scheduled for major abdominal operations.

\section{Methods}

Ten unpremedicated patients (ages 17-60) without known renal disease who were about to undergo vascular or gastro-intestinal surgery were studied approximately four to six hours before their operations were to begin. Informed written consent was obtained at the time of the preoperative visit. Before the experiments began each patient had two intravenous infusions started in the upper extremities, a central venous pressure catheter placed in the antecubital fossa and threaded to the right atrium, and a radial-artery catheter inserted. A catheter was also inserted into the urinary bladder and standard electrocardiograph leads were applied to the extremities. With the patients in a recumbent position, oxygen was then given by face mask and a diuresis was started by intravenous administration of lactated Ringer's solution at a rate of $25 \mathrm{ml} / \mathrm{min}$. When urine output became more than $5 \mathrm{ml} / \mathrm{min}$, the bladder catheter and collecting bag were emptied and the first of three 20-minute urine collections was begun. At the end of each collecting period complete emptying of the bladder was insured by suprapubic pressure. Urine collected was then measured and analyzed immediately for osmolarity and creatinine. At the end of each 20 -minute collecting period a $10-\mathrm{ml}$ blood sample was obtained for measurement of osmolarity and creatinine.

-Assistant Professor of Anesthesiology and Surgery, University of Utah College of Medicine, Salt Lake City, Utah 84132.

†Lt.C., M.C., Staff Anesthesiologist, Wilford Hall U.S.A.F. Medical Center, San Antonio, Texas 78236.

tResident in Anesthesiology, University of Utah College of Medicine, Salt Lake City, Utah 84132.

\$Col., M.C., Staff Nephrologist, Wilford Hall U.S.A.F. Medical Center, San Antonio, Texas 78236.

From the Divisions of Anesthesiology and Artificial Organs, the University of Utah College of Medicine, 50 North Medical Drive, Salt Lake City, Utah 84132 and the Divisions of Anesthesiology and Medicine of the Wilford Hall USAF Medical Center, San Antonio, Texas 78236. 
Following the first hour of control measurements, morphine sulfate was given at rates of 5 to $15 \mathrm{mg} / \mathrm{min}$. Breathing of 100 per cent oxygen continued. After 0.25 $\mathrm{mg} / \mathrm{kg}$ of morphine, respirations were assisted and after $1.0 \mathrm{mg} / \mathrm{kg}$ were controlled. Arterial Pco.2 was maintained between 35 and 45 torr, as measured in radial artery blood obtained every 20 minutes. After $2 \mathrm{mg} / \mathrm{kg}$ of morphine had been given, the bladder catheter and collecting bag were again emptied and the urine and blood sampling of the control period were repeated. The inspired gas was then changed to 60 per cent nitrous oxide in oxygen. After a 15-minute equilibration period a final hour of urine and blood sampling was performed as before.

Osmolarity of urine and blood samples was determined with an Advanced Osmometer. Creatinine was measured in urine and blood by a modification of the method of Bonsues and Taussky 4 and creatinine, osmolar and free water clearances were determined using the standard clearance equation.

\section{Results}

Mean values of all urine and blood parameters measured during each of the three study periods appear in Table I. Morphine did not significantly change urine output, urine and plasma osmolarity, or creatinine, osmolar or free water clearances when compared to the control period. Mean systolic and diastolic blood pressures were also unaffected by morphine (Table II). Addition of 60 per cent nitrous oxide to the gas inspired by these patients who previously had large doses of morphia significantly increased urine osmolarity and decreased urine output. Urinary osmolarity was almost doubled, while flow decreased an average of 61 per cent after nitrous oxide. Mean systolic and diastolic arterial blood pressures were slightly but significantly reduced, while creatinine, osmolar and free water clearances were markedly diminished by $\mathrm{N}_{2} \mathrm{O}$.

\section{Discussion}

This study demonstrates that anaesthetic doses of morphine $(2 \mathrm{mg} / \mathrm{kg})$ with breathing of oxygen do not significantly affect urinary output in adequately ventilated supine patients undergoing diuresis produced by infusion of lactated Ringer's solution. It also indicates that adding 60 per cent nitrous oxide to these patients markedly alters renal function and reduces urine flow.

The effects of morphine on the kidney have been extensively studied in man and other animals. ${ }^{5-14}$ Most investigators have found that morphine has significant antidiuretic properties but the mechanisms are different in different animal species. There is evidence in dogs and rats that morphine antidiuresis may be attributed to a release of antidiuretic hormone $(\mathrm{ADH}){ }^{\mathbf{5}, \mathbf{6}} \mathrm{In}$ man therapeutic doses of morphine (10-30 mg) do not stimulate ADH release except in unusual circumstances, i.e. when nausea and vomiting occur. ${ }^{7-11}$ Antidiuresis after morphine in patients has therefore been related to a decrease in renal blood flow. ${ }^{11}$ Papper, Saxon, Burg and Seifer ${ }^{8}$ and Deutsch, Bastron, Pierce and Vandam ${ }^{7}$ demonstrated a decrease in glomerular filtration rate (GFR) after 10-30 mg of morphine in man and suggested that this is the primary cause of reduced urine flow after use of the drug. 
TABLE I

The Effects of Morphine and Morphine plus Nitrous Oxide on Renal Function in Ten Patients

\begin{tabular}{|c|c|c|c|}
\hline & $\begin{array}{l}\text { 1st Study } \\
\text { Period }\end{array}$ & $\begin{array}{l}\text { 2nd Study } \\
\text { Period }\end{array}$ & $\begin{array}{l}\text { 3rd Study } \\
\text { Period }\end{array}$ \\
\hline Anaesthesia & None & $\begin{array}{l}\text { Morphine } \\
2 \mathrm{mg} / \mathrm{kg}\end{array}$ & $\begin{array}{l}\text { Morphine } 2 \mathrm{mg} / \mathrm{kg} \\
+\mathrm{N}_{2} \mathrm{O}(60 \%)\end{array}$ \\
\hline $\begin{array}{l}\text { Per cent Oxygen } \\
\text { Lactated Ringer's }\end{array}$ & $100 \%$ & $100 \%$ & $40 \%$ \\
\hline I.V. Flow Rate $(\mathrm{ml} / \mathrm{min})$ & 25 & 25 & 25 \\
\hline Urine Output (ml) & 469 & 476 & $184^{*}$ \\
\hline Urine Flow Rate $(\mathrm{ml} / \mathrm{min})$ & 7.8 & 7.9 & $3.1^{*}$ \\
\hline Creatinine Clearance (ml/min) & 128 & 121 & $81^{*}$ \\
\hline Plasma Osmolarity (mOsm $/ \mathrm{kg}$ ) & 284 & 283 & 281 \\
\hline Urine Osmolarity $(\mathrm{mOsm} / \mathrm{kg})$ & 80 & 79 & $145^{*}$ \\
\hline Osmolar Clearance $(\mathrm{ml} / \mathrm{min})$ & 2.2 & 2.2 & $1.6^{*}$ \\
\hline Free Water Clearance $(\mathrm{ml} / \mathrm{min})$ & 5.6 & 5.7 & $1.5^{*}$ \\
\hline
\end{tabular}

${ }^{*} \mathrm{P}<0.01$, Students $\mathrm{t}-\mathrm{Test}$ for paired data when compared to 1 st-study period values.

TABLE II

Mean Blood Pressures Before and After Morphine and Morphine plus 60 Per cent Nitrous Oxide

\begin{tabular}{lccc}
\hline & Control Period & After Morphine $(2 \mathrm{mg} / \mathrm{kg})$ & $\begin{array}{c}\text { After Morphine }(2 \mathrm{mg} / \mathrm{kg}) \\
\text { plus } \mathrm{N}_{2} \mathrm{O}\end{array}$ \\
\hline $\begin{array}{l}\text { Systolic Blood Pressure } \\
(\mathrm{mm} \mathrm{Hg})\end{array}$ & 127 & 129 & $111^{*}$ \\
$\begin{array}{l}\text { Diastolic Blood Pressure } \\
(\mathrm{mm} \mathrm{Hg})\end{array}$ & 79 & 82 & $73^{*}$ \\
\hline${ }^{* \mathrm{P}<0.05}$ when compared to control values using students t-test for paired data.
\end{tabular}

Some investigators have been unable to demonstrate a decrease in urinary output after therapeutic doses of morphine. ${ }^{12-1+}$ Walker $^{12}$ found that healthy students subjected to a water diuresis showed no evidence of antidiuresis after subcutaneous administration of $20 \mathrm{mg}$ of morphine. Hopmann ${ }^{13}$ showed that morphine, rather than inhibiting, promoted a diuresis in patients with cardiac failure. Ferrer and Sokoloff ${ }^{14}$ demonstrated that intramuscular administration of $10 \mathrm{mg}$ of morphine decreased urine output in three of nine patients subjected to a mercurial diuresis, but had no influence on the renal function of the other six. Although reasons for the diversity of findings in these studies and those of Papper and his associates, ${ }^{8}$ Deutsch et al. ${ }^{7}$ and others ${ }^{5,6,9-11}$ are not clear, one explanation could be different experimental methods and thus varying systemic cardiovascular dynamics. In none of the studies mentioned was arterial PCo.2 $_{2}$ or cardiac output measured or controlled and arterial blood pressure was monitored in only three studies. Increases in arterial $\mathrm{PcO}_{2}$, a likely situation in patients receiving morphine without respiratory assistance, are known to stimulate endogenous cathecholamine release $\mathrm{e}^{16.17}$ and decrease renal blood flow, GFR and urine output. ${ }^{18-2 n}$ Decreases in Pco.2, cardiac output or arterial blood pressure can also diminish renal blood flow. ${ }^{21.22}$ Handley and Moyer ${ }^{10}$ suggested on the basis of experiments in dogs that the antidiuretic effects of morphine are primarily due to hypotension with secondary renal vasoconstriction. When hypotension did not occur most of their dogs did not sustain a change in renal 
funotion after as much as $2 \mathrm{mg} / \mathrm{kg}$ of intravenous morphine. Our results in supine man appear to corroborate those of Handley and Moyer in dogs. Furthermore, in a number of the studies cited above, patients were required to stand and to void after the administration of morphine. Although morphine has been shown to have little effect on cardiovascular dynamics in supine man $^{1}$ as little as $10 \mathrm{mg}$ can cause enough vasodilation and peripheral pooling to result in a significant decrease in cardiac output and arterial blood pressure on sitting or standing. ${ }^{15}$ This could easily explain reduced renal blood flow and urine output in these patients.

There has been only one previous report specifically investigating the effects of anaesthetic doses of morphine on renal function in man. ${ }^{3}$ In that study Mannheimer found that an average of $3 \mathrm{mg} / \mathrm{kg}$ of morphine plus 50 per cent nitrous oxide caused a marked antidiuresis during open-heart surgery, when compared to halothane with nitrous oxide. He also found that the addition of 5 per cent intravenous alcohol to the anaesthetic regiment prevented the antidiuresis. On the basis of these findings he suggested that morphine stimulates $\mathrm{ADH}$ release which ethanol inhibits. As mentioned above Deutsch et al. ${ }^{7}$ and others ${ }^{8-11}$ have demonstrated that therapeutic doses of morphine have no ADH releasing effects in man. Our results in this study suggest that this is also true when anaesthetic doses of morphine are used but possibly not, as Mannheimer concluded, when nitrous oxide is employed in addition to the morphine. Whether nitrous oxide acts primarily by releasing ADH or by decreasing GFR in these patients cannot be determined from our results since creatinine clearance (a measure of GFR) and urine osmolarity (a measure of $\mathrm{ADH}$ release) were both markedly altered. However, in a recent report McDermott and Stanley ${ }^{23}$ demonstrated that 50 per cent $\mathrm{N}_{2} \mathrm{O}$ decreased cardiac output by an average of 40 per cent in patients who had received $2 \mathrm{mg} / \mathrm{kg}$ of morphine. This suggests that a large component of $\mathrm{N}_{2} \mathrm{O}$ antidiuresis in patients receiving large doses of morphine may be due to a reduction in renal blood flow. If this was so in Mannheimer's patients receiving morphine, then the 5 per cent alcohol (an extremely hyperosmotic agent with an osmolarity of $1087 \mathrm{mOsm} / \mathrm{L}$ vs $280 \mathrm{mOsm} / \mathrm{L}$ for normal plasma) he used to avoid antidiuresis may have done so by increasing intravascular volume, cardiac output and secondarily renal blood flow. Unfortunately, since cardiac output and renal blood flow were not measured either in Mannheimer's patients or in ours, we cannot definitely say what effect nitrous oxide, or for that matter, 5 per cent ethanol had on renal blood flow in these studies.

\section{SUMMARY}

Renal effects of anaesthetic doses of morphine $(2 \mathrm{mg} / \mathrm{kg})$ were determined in 10 patients before and after the addition of 60 per cent nitrous oxide. While morphine had no effect on systemic arterial blood pressure, urinary osmolarity and output, or creatinine, osmolar or free water clearances the addition of nitrous oxide resulted in a reduction in all of these except urine osmolarity, which was significantly increased. These findings demonstrate that large doses of morphine are not antidiuretic in man, but suggest that morphine plus nitrous oxide markedly alters renal function. 


\section{RÉSUMÉ}

Chez 10 patients devant subir une chirurgie abdominale majeure, nous avons déterminé les effets sur le débit urinaire de la morphine en doses anesthésiques ( 2 $\mathrm{mg} / \mathrm{kg}$ ) avec et sans l'addition de protoxyde d'azote. La morphine n'a pas altéré de façon significative la tension artérielle, ni le débit urinaire, chez les patients bien ventilés, en position dorsale et soumis à une diurèse au Lactate Ringer. L'addition de 60 pour cent de protoxyde d'azote chez des patients déjà anesthésiés à la morphine a provoqué un léger abaissement de la tension artérielle et une diminution marquée du débit urinaire et des clearances osmolaire, hydrique et de la créatinine; l'osmolarité urinaire fut augmentée. Ces résultats démontrent que les doses importantes de morphine n'altèrent pas la fonction rénale chez l'homme, mais que la morphine accompagnée de protoxyde d'azote a un pouvoir antidiurétique extrêmement puissant.

\section{REFERENCES}

1. Lowenstein, E., Hallowell, P., Levine, F.H., Daggett, W.M., Austen, G., \& Laver, M.B. Cardiovascular response to large doses of intravenous morphine in man. N. Engl. J. Med. 281: 1389 (1969).

2. Hasbrouck, J.D. Morphine anesthesia for open-heart surgery. Ann. Thorac. Surg. 10: 364 (1970).

3. Mannheimer, W.H. The use of morphine and intravenous alcohol in the anesthetic management of open-heart surgery. South. Med. J. 64: 1125 (1971).

4. Bonsues, R.W. \& TAUSSKY, H.H. On the colorimetric determination of creatinine by the Jaffe reaction. J. Biol. Chem. 158: 581 (1945).

5. Giamman, N.J., Mattie, L.R., \& Stephenson, W.F. Studies on the antidiuretic action of morphine. Science 117: 225 (1953).

6. DeBodo, R.C. The antidiuretic action of morphine and its mechanism. J. Pharmacol. Exper. Therap. 82: 74 (1944).

7. Deutsch, S., Bastron, R.D., Pience, E.C., \& Vandam, L.D. The effects of anaesthesia with thiopentone, nitrous oxide, narcotics and neuromuscular blocking drugs on renal function in normal man. Brit. J. Anaesth. 41: 807 (1969).

8. Papper, S., Saxon, L., Burg, M.B., Seifer, H.W., \& Rosenbaum, J.D. The effect of morphine sulfate upon the renal excretion of water and solute in man. J. Lab. \& Clin. Med. 50: 692 (1957).

9. Brown, W.E., Hodges, R., \& Bradbury, J.T. Effects of morphine on renal clearances of para-amino hippurate and sodium thiosulfate in the human kidney. Am. J. Med. 6: 663 (1949).

10. Handley, C.A. \& Moyer, J.H. The mechanism of the renal effects of morphine. Arch. Internat. Pharmacodyn. 90: 185 (1952).

11. Papper, S. \& Pappen, E.M. The effects of preanesthetic, anesthetic, and postoperative drugs on renal function. Clin. Pharmacol. Thera. 5: 205 (1964).

12. WaLKER, J.M. The effects of smoking on water diuresis in man. Quart. J. Med. 18: 51 (1949).

13. Hopmann, R. Die Diuresestergerung durch Morphin und Andre Schlafmittel bei Erkerankungen des Kreislaufapparates Ataschr. f. klin. Med. 107: 582 (1928).

14. Ferrer, 1.M. \& SokolofF, L. The antidiuretic effect of morphine and demerol in congestive heart failure. Am. J. Med. Sci. 214: 372 (1947).

15. Drew, J.H., Dripps, R.D., \& Comroe, J.H. Clinical studies on morphine II. The effect of morphine upon the circulation of man and upon the circulatory and respiratory responses to tilting. Anesthesiology, 7: 44 (1946).

16. Richardson, J.A. \& Woods, E.F. Effect of carbon dioxide inhalation on plasma concentrations of epinephrine and arterenol. Fed. Prod. 15: 473 (1956). 
17. MiLleR, R.A. Plasma adrenaline and noradrenaline during diffusion respiration. J. Physiol. 150: $79(1960)$.

18. Fonster, R.P. \& Nyboer, J. Effect of induced apnea on cardiovascular renal functions in rabbit. Amer. J. Physiol. 183: 149 (1955).

19. Franklin, K.J., McGee, L.E., \& Ullaran, E.A. Effects of severe Asphyxia on kidney and urine flow. J. Physiol. 112; 43 (1951).

20. Drapen, W.B. \& Whitehead, R.W. Diffusion respiration in dogs anesthetized by Pentothal sodium. Anesthesiology 5: 262 (1944).

21. Stanbury, S.W. \& Thomson, A.E. Renal response to respiratory alkalosis. Clin. Sci. 11 ; 357 (1952).

22. Selkunt, E.E. Renal blood flow and renal clearance during hemorrhagic shock. Am. J. Physiol. 145: 699 (1946).

23. McDermott, R. \& Stanley, T.H. The effects of low concentrations of nitrous oxide on cardiovascular dynamics during morphine anesthesia. Abstracts of Scientific Papers, 1973 Annual Meeting, American Society of Anesthesiologists, pp. 249-250. 